\title{
Micropropagation of Liriope muscari via leaf explant 1
}

\author{
Keithley L. Amory² and John M. Gill ${ }^{3}$
}

J. Agric. Univ. P.R. 83(3-4):169-173 (1999)

\begin{abstract}
Young leaves of Liriope muscari provide an ample source of explants for in vitro propagation in tropical countries where flowering is scarce. Leaves were induced to form calli on a solid medium containing Murashige and Skoog (MS) salts and vitamins, $3 \%$ sucrose, $0.7 \%$ agar, $1 \mathrm{mg} / \mathrm{L} 2,4$-dichlorophenoxy-acetic acid (2, 4-D) and $1 \mathrm{mg} / \mathrm{L}$ 6-furfurylaminopurine (kinetin). Only the proximal segments of the leaves produced calli. These calli were induced to produce multiple plantlets on MS medium, $3 \%$ sucrose, $0.7 \%$ agar, and $10 \mathrm{mg} / \mathrm{L} \mathrm{N}^{6}$ (2-isopentenyl) adenine (2 ip). It is possible to use leaf explants for in vitro mass production of Liriope. However, in variegated varieties, only green or white plants were produced, because of a chimera in the original tissue.
\end{abstract}

Keywords: Tissue culture, Liriope muscari, growth regulators, leaf tissue

\section{RESUMEN}

Micropropagación de Liriope muscari por explante de hoja

Los explantes de hojas jóvenes de Liriope muscari ofrecen una fuente de gran disponibilidad para propagación in vitro en paises de climas cálidos donde la florecida es escasa. Se obtuvo callo de hojas tiernas colocadas en medio sólido de sales y vitaminas de Murashige and Skoog (MS), 3\% sucrosa, $0.7 \%$ agar, y los reguladores de crecimiento ácido 2,4-diclorofenoxiácetico (2, 4-D) a $1 \mathrm{mg} / \mathrm{L}$ y 6 -furfurilaminopurina (kinetina) a $1 \mathrm{mg} / \mathrm{L}$. Se obtuvo callo sólo del área proximal de las hojas. Este callo produjo plántulas al ser colocado en medio de MS, $3 \%$ sucrosa, $0.7 \%$ agar y la citoquinina $\mathrm{N}^{6}$ (2-isopentenil) adenina (2 ip) a $10 \mathrm{mg} / \mathrm{L}$. El uso de secciones de hojas como fuente de explante para la propagación en masa de Liriope es posible. Sin embargo, en variedades variegadas, sólo se obtuvieron plantas de colores verdes o blancas debido posiblemente a una quimera en el tejìdo original.

\section{INTRODUCTION}

In fiscal year 1996 , foliage plants contributed $30 \%$ of the $\$ 33$ million (gross income) earned from the sale of ornamental plants in Puerto

'Manuscript submitted to the Editorial Board 25 May 1998.

2Research Associate, Department of Horticulture, UPR-Mayagüez Campus, P.O. Box 9030, Mayagüez, P.R. 00681.

"Associate Professor, Department of Horticulture, UPR-Mayagüez Campus. 
Rico (Department of Agriculture, 1996). The foliage industry is presently undergoing a growth spurt because of an increase in urban development (Anon., 1997). With the increase in urban development, local landscapers have placed a heavy demand on the use of Liriope muscari cultivars. Liriope is used as a groundcover, edging plant for densely shaded or sunny areas, in high erosion areas because it is decorative and requires little maintenance (Watkins and Sheehan, 1994; Hériteau, 1990). Two varieties of Liriope are sold in Puerto Rico. The most common is green; however, the variegated cultivar (green and white) is the more popular and in greater demand.

Because of this demand, Liriope is imported from Florida and Costa Rica at an average cost of $\$ 0.40$ per plant. Annually, an average of 200,000 plants are imported by the growers who specialize in Liriope production (F. Castillo, Plantas Tropicales, Río Piedras, PR; C. Morales, Rico Plants, Aibonito, PR, personal communication). These plants are then propagated vegetatively by clump division. However, local producers have reported that slow growth and development has limited its availability. About 15 off-shoots may develop from one mother plant in one year (N. González, Univ. Puerto Rico, Mayagüez Campus, PR, personal communication).

Information on tissue culture of Liriope is scarce. Mullin (1970) produced only roots when he used tuberized root pieces as explants, whereas Frett and Dirr (1983) were successful in producing plantlets by using inflorescence and scape tissues. Since then, no research has been published on the growth and development of this plant in tissue culture. Flowering is rarely observed in Puerto Rico but has been seen in mature stock plants more than six years old. However, flowering has been reported during the spring and summer in Florida, where the Plant Hardiness Zone is 10 . The average annual minimum temperature for this zone ranges from $-1.1^{\circ} \mathrm{C}$ to $4.4^{\circ} \mathrm{C}$ (Watkins and Sheehan, 1994; Broschat and Meerow, 1991). The reasons for limited flowering in Puerto Rico are not clear and need to be addressed in future research. Factors such as photoperiod, temperature and hormonal balance may be playing an important role.

The mass propagation of Liriope via tissue culture could be used to reduce importation and increase availability. In this paper, we report the use of young leaves as a source of explants for plantlet production.

\section{MATERLALS AND METHODS}

Young leaves, 2 to $3 \mathrm{~cm}$ or less in length, of field grown variegated plants of $L$. muscari were used as explants. The leaves were first washed under running tap water for 10 minutes, then sterilized by 
placing them in a solution of $20 \% \mathrm{v} / \mathrm{v}$ Clorox $\mathrm{x}^{4}$ and $1 \% \mathrm{v} / \mathrm{v}$ of Polyoxyethylene sorbitan (Tween 20) for 10 minutes. They were then rinsed three times with sterile distilled water. After removal of the borders damaged by disinfestation, the leaves were cut into $\pm 1 \mathrm{~cm}$ sections and placed adaxial side on a callus inducing medium comprised of basal Murashige and Skoog (MS) salts (1962), 3\% sucrose, 0.7\% agar, $1 \mathrm{mg} / \mathrm{L} \mathrm{2,4-}$ dichlorophenoxy-acetic acid (2, 4-D) and $1 \mathrm{mg} / \mathrm{L}$-furfurylaminopurine (kinetin). Ten $\mathrm{ml}$ was dispensed into \#2 Dram vials and autoclaved at $121^{\circ} \mathrm{C}$ and $1.1 \mathrm{~kg} / \mathrm{cm}^{2}$ for 20 minutes. Fifty \pm 1 -cm segments, including 15 tip, 15 central, and 20 basal segments, were planted in a complete randomized design in a Wheaton rack and maintained at $25^{\circ} \mathrm{C}$ in the dark. After 12 weeks, the calli were transferred to a shoot regeneration medium composed of basal MS, $3 \%$ sucrose, $0.7 \%$ agar and $10 \mathrm{mg} / \mathrm{L} \mathrm{N}{ }^{6}$ (2-isopentenyl) adenine ( $2 \mathrm{ip}$ ). Shoots were maintained at $25^{\circ} \mathrm{C}, 21.43$ $\mu \mathrm{mol} / \mathrm{m}^{2} / \mathrm{s}$ light intensity with 16 -h photoperiod. The number of tubes and segments forming calli was analyzed by using the Fisher's Exact Test in SAS program (Steel and Torrie, 1980).

\section{RESULTS AND DISCUSSION}

After 12 weeks in culture, white compact calli were observed only in the central and basal portions. There were significant differences in the number of segments forming calli between the tip and the other two segments. The Fisher's Exact Test showed no significant difference between the central and basal segments (Table 1).

Calli production was not abundant and arose mainly from the cut surfaces. The basal 1-cm segment had, visually, the most calli. This finding may be due to the accumulation of internal auxin at the base of the leaf sheath as a result of basipetal movement within the leaves (Taiz and Zeiger, 1991), as well as to the dedifferentiation of the intercalary meristem at the leaf base (Esau, 1965). It also suggests that there may be a positional effect (Guiderdoni and Demarly, 1988).

After the initial 12 weeks, the callus was subcultured onto fresh medium to increase its volume. Meristematic centers (green spots) appeared four to six weeks after subculture. The presence of kinetin in the medium may have promoted these meristematic centers. Meristematic center formation in monocots (Amaryllidaceae) has been documented by Shahin and Kaneko (1986), who reported that the presence of kinetin in the medium was critical for shoot proliferated in the

"Trade names in this publication are used only to provide specific information. Mention of a trade name does not constitute a warranty or endorsement of equipment or material by the Agricultural Experiment Station. 
TABLE 1.-Number and percentage of tubes with and without calli formation based on 50 leaf segments.

\begin{tabular}{lccc}
\hline Leaf segment & $\begin{array}{c}\text { No. of tubes } \\
\text { with callus }\end{array}$ & $\begin{array}{c}\text { No. of tubes } \\
\text { without callus }\end{array}$ & $\begin{array}{c}\text { Total number } \\
\text { of tubes }\end{array}$ \\
\hline Base & $6(30 \%) b^{1}$ & $14(70 \%)$ & 20 \\
Central & $4(27 \%) \mathrm{b}$ & $11(73 \%)$ & 15 \\
Tip & $0(0 \%) \mathrm{a}$ & $15(100 \%)$ & 15 \\
Total & $10(20 \%)$ & $40(80 \%)$ & 50 \\
\hline
\end{tabular}

'Numbers in the same column with the same letter are not significantly different from each other at $\mathrm{P}<0.05$.

callus of nonbulbing onions. Multiple green and albino Liriope shoots were produced via organogenesis from these meristematic centers of the calli, with some root production on the shoot-inducing medium. The use of a natural cytokinin ( 2 ip) may have been beneficial to shoot and plantlet regeneration. Possibly the variegated Liriope is a genetic mosaicism (chimera) in which two cells of different genotypes coexist and its phenotype (white or green) will depend on the tissue from which the shoots regenerated. Frett and Dirr (1983) also reported chimeric segregation in variegated Liriope with calli derived from inflorescence after an eight-week induction period on modified MS supplemented with 2 $\mathrm{mg}$ indole-3-acetic acid (IAA) and $2 \mathrm{mg}$ kinetin.

The albino shoots have retained this condition over several subcultures. However, they did not survive on transferal to the greenhouse. Their survival is possible only if they share a common root system with a normal plant, as observed in tissue culture, and will grow at a slower rate than the normal plant. Marcotrigiano (1997) reported that in green and white variegated plants, the albino tissue is at a disadvantage because these cells do not divide as frequently as green tissue or stop dividing earlier.

Regeneration of variegated chimeral plants can be maintained by stem cuttings, grafting, leaf-bud cuttings, division or by using apical and lateral buds as explants in tissue culture (Marcotrigiano, 1991). However, the variegated cultivars of Liriope have been difficult to propagate in tissue culture because of the great variability in segregation of the resulting plantlets (Berry, 1995). We have established apical and lateral meristems of variegated Liriope in tissue culture and also have observed variants in the variegated pattern. Apparently, in micropropagation of variegated Liriope, variegation is conserved but not the parental patterns. The maintenance of identical patterns of variegation may occur only if the dissimilar cells, which cause variegation, remain 
independent in the apical/lateral meristems, and continue to divide to give rise to the cells that form the body of the plant (Marcotrigiano, 1997; 1991). Stewart and Dermen (1979) reported that the variability in leaf patterns may be caused by these differences in the apical layers, which are common in monocots.

The use of leaf explant for the mass production of Liriope is possible. However, regeneration of variegated plants via calli production will be limited by the above factors. Apical and lateral buds can be used to produce variants, which can then be maintained by clump division. Research will continue with emphasis on the optimization of a medium for mass production using apical and lateral meristems as explants.

\section{LITERATURE CITED}

Anon., 1997. Puerto Rico Forestry Conference 1997. Dedicated to improving Puerto Rico Urban Forestry. P.R. 1997.

Berry, T., 1995. Liriope nuscari production and use in the southeastern United States. Comb. Proc: Intl. Plant Prop. Soc. 45: 165-168.

Broschat, T. K. and A. W. Meerow, 1991. Betrock's reference Guide to Florida Landscape Plants. Betrock Information Systems, Inc.

Department of Agriculture, 1996. Gross Agriculture Income of Puerto Rico, Agriculture Statistic Office, Department of Agriculture of Puerto Rico, Santurce, P.R.

Esau, K., 1965. Plant Anatomy. 2nd ed. John Wiley and Sons, Inc., New York.

Frett, L. and M. A. Dirx, 1983. Tissue culture propagation of Liriope muscari and Ophiopogon jaburan. Hort Science. 18(4):431-432.

Guiderdoni, E. L. and Y. Demarly, 1988. Histology of somatic embryogenesis in cultured leaf segments of sugrarcane plantlets. Plant Cell, Tissue and Organ Culture 14:71-88.

Hériteau, J., 1990. The Nutional Arboretum Book of outstanding garden plants: the authoritative guide to selecting and growing the most beautiful, durable, and carefree garden plants in North America. A Stonesong Press Inc. New York, New York.

Marcotrigiano, M., 1997. Chimeras and Variegation: Patterns of Deceit. HortScience. 32(5):773-786.

Marcotrigiano, M., 1991. Understanding foliar varicgation as it relates to propagation. Comb. Proc. Intl. Plant Prop. Soc. 41:410-415.

Mullin, M., 1970. Tissue culture of some monocotyledoneous plants. Aust. J. Biol. Sci. 23:473-477.

Murashige, T. and F. Skoog, 1962. A revised medium for rapid growth and bioassays with tobacco tissue cultures. Physiol. Plant. 15:473-497.

Shahin, E. A. and K. Kaneko, 1986. Somatic embryogenesis and plant regeneration from callus cultures of nonbulbing onions. HortScience. 21(2):294-295.

Steel, R. G. D and J. H. Torrie, 1980. Principles and Procedures of Statistics. A Biometrical Approach. 2nd ed. McGraw-Hill Book Company, New York, New York.

Stewart, R. N. and H. Dermen, 1979. Ontogeny in monocotyledons as revealed by studies of the developmental anatomy of periclinal chloroplast chimeras. Amer. d. Bot $66: 47-58$.

Taiz, L. and E. Zeiger, 1991. Plant Physiology. The Benjamin/Cummings Publishing Company Inc. New York, New York.

Watkins, J. V. and T. J. Sheehan, 1994. Florida Landscape Plants. Native and Exotic. Revised Edition. The University Presses of Florida, Gainesville, Florida. 